\title{
TRADISI BERBURU SUKU BAUZI DI MAMBERAMO RAYA (Hunter Tradition of Bauzi Tribe in Mamberamo Raya)
}

\author{
Hari Suroto \\ Balai Arkeologi Jayapura \\ hariprimitiveart@gmail.com
}

\begin{abstract}
Especially prehistoric tradition of hunting and gathering tradition has continued until today in Bauzi tribe in Mamberamo Raya. This paper aims to discuss the tradition of hunting on Bauzi tribe, hunting equipment used and the strategy used in hunting. This study is descriptive and exploratory. Data collection was done of the literature study and interviews. Hunting animals is an activity undertaken Bauzi tribe throughout the year. Hunting methods used by individuals that hunt, hunt groups, and hunt groups using dogs. The strategy used in the hunt that is trapping, reconnaissance and attack suddenly, diving and attacked the crocodile in the water. Animal bone as a tool used in everyday life Bauzi tribe.
\end{abstract}

Keywords: Bauzi tribe, the traditions of hunting, hunting equipment

\begin{abstract}
ABSTRAK
Tradisi prasejarah terutama tradisi berburu dan meramu masih berlangsung hingga saat ini pada suku Bauzi di Mamberamo Raya. Tulisan ini bertujuan untuk membahas tradisi berburu pada suku Bauzi, peralatan berburu yang digunakan dan strategi yang dipakai dalam berburu. Penelitian ini bersifat deskriptif dengan bentuk penalaran induktif dan pendekatan kualitatif, serta pendekatan etnoarkeologi. Pengumpulan data yang dilakukan yaitu dengan studi kepustakaan, observasi lapangan dan wawancara. Berburu binatang merupakan aktivitas suku Bauzi yang dilakukan sepanjang tahun. Metode berburu yang digunakan yaitu berburu yang dilakukan individu, berburu kelompok, serta berburu kelompok menggunakan anjing. Strategi yang digunakan dalam berburu yaitu pemasangan perangkap, pengintaian serta penyerangan mendadak, menyelam dan menyerang buaya dalam air. Tulang binatang buruan dimanfaatkan sebagai bahan alat dalam kehidupan sehari-hari suku Bauzi.
\end{abstract}

Kata kunci: Suku Bauzi, tradisi berburu, peralatan berburu

Tanggal masuk : 19 September 2014

Tanggal diterima : 3 November 2014 


\section{PENDAHULUAN}

Kabupaten Mamberamo Raya secara geografis terletak antara $137^{\circ}$ $46-140^{\circ} 19$ Bujur Timur dan $01^{\circ} 28-3^{\circ}$ 50 Lintang Selatan. Nama kabupaten ini diambil dari nama sungai besar yang mengalir di wilayah ini, istilah "Mamberamo" sendiri berasal dari bahasa Dani - mambe berarti "besar" dan ramo berarti "air" (http://www. mamberamorayakab.go.id).

Sungai Mamberamo merupakan sungai sepanjang $670 \mathrm{Km}$, kedalaman sungai berkisar antara 8 hingga $33 \mathrm{~m}$, debit airnya $5.500 \mathrm{~m}^{3} /$ detik. Penduduk asli Mamberamo adalah suku Bauzi. Penduduk setempat mengandalkan Sungai Mamberamo sebagai prasarana transportasi yang menghubungkan antara pegunungan Papua (Tolikara) dengan pesisir utara (Waropen, Yapen, Biak, Sarmi). Suku Bauzi bermukim di daerah Mamberamo hulu mendapat pengaruh budaya dari suku Yali dan Dani. Sedangkan penduduk Mamberamo yang mendiami sekitar sepanjang aliran Sungai Mamberamo hingga hilir mendapat pengaruh dari suku Waropen, Sarmi dan kepulauan Yapen dan Biak.

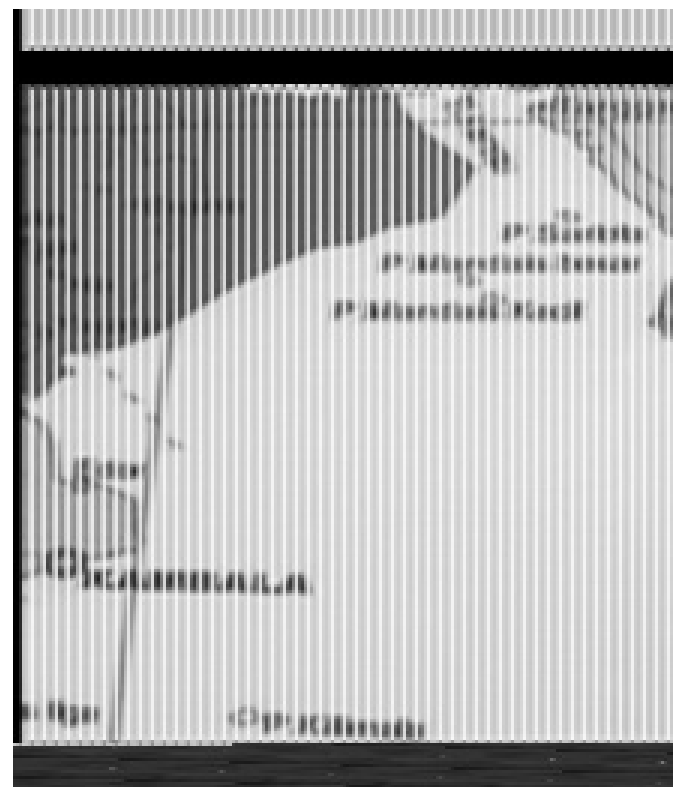

Peta Mamberamo Raya (sumber: http://lightbeing.org)
Luas wilayah Kabupaten

Mamberamo Raya yaitu 23.813,91 $\mathrm{km}^{2}$, dengan jumlah penduduk hanya 21.888 jiwa (Sensus Penduduk 2011), sehingga diketahui rata-rata tingkat kepadatan penduduk per kilometer persegi hanya satu orang. Penduduk Mamberamo hidup dalam kelompokkelompok yang sangat kecil dengan sekitar 15-30 orang (Reuter, 2010:318), mereka membangun perkampungan di sepanjang sungai (Lamera dan Siregar, 1994:215).

Kondisi geografi dan alam mempengaruhi sistem mata pencaharian mereka sehingga terlihat bahwa suku Bauzi yang mendiami Distrik Mamberamo Hulu dan Distrik Mamberamo Tengah mata pencahariannya adalah menokok sagu, berkebun, berburu dan menangkap ikan. Sedangkan suku Bauzi yang mendiami Distrik Mamberamo Hilir, Waropen Atas, Benuki dan Sawai bermata pencaharian menokok sagu dan menangkap ikan.

Walaupun posisi Mamberamo berada di pedalaman, tetapi wilayah ini menjadi titik temu antara penduduk pegunungan dan pantai. Reuter (2010:52) berpendapat kerang-kerang laut yang ada di daerah pegunungan dan kelangkaannya sebagai alat bayar, merupakan bukti adanya hubungan antara daerah pantai dan pegunungan. Hal ini sependapat dengan Muller (2008:74) yang menyatakan bahwa masyarakat yang bermukim di wilayah pinggiran pegunungan sering bepergian ke dataran rendah untuk mengambil kayu pohon palem hitam sekaligus melakukan barter dengan penduduk dataran rendah. Umumnya alat barter penduduk dataran tinggi adalah tembakau dan bulu burung. Kedua jenis komoditi ini biasanya ditukar dengan cangkang kerang dan busur dari palem hitam. Komoditas perdagangan suku Dani dan Yali menurut Koentjaraningrat (1963:221) adalah babi, 
bahan kapak batu dan kapak batu untuk ditukar dengan kerang cypraea moneta, bulu burung cenderawasih, manik-manik, jaring, damar, garam, dan sagu.

Tradisi prasejarah terutama tradisi berburu dan meramu masih berlangsung hingga saat ini pada suku Bauzi. Berburumasih termasuk sebagai kegiatan utama karena hewan buruan masih relatif melimpah. Beberapa masyarakat Bauzi yang tinggal di hulu sungai Mamberamo kondisi tanahnya cocok untuk pertanian, tetap enggan bercocok tanam dan hanya meluangkan sedikit waktu untuk memelihara tanaman mereka. Tulisan ini bertujuan untuk membahas tradisi berburu yang masih berlangsung pada suku Bauzi, peralatan berburu yang digunakan dan teknik yang dipakai dalam berburu. Penelitian ini bersifat deskriptif dan eksploratif. Menurut James Deetz (1967:6) terdapat tiga tingkatan dalam penelitian arkeologi. Ketiga tingkatan itu adalah observasi (observation) merupakan tingkat pengumpulan data, deskripsi (description), tingkat pengolahan data dan penjelasan (explanation) adalah tingkat interpretasi data.

\section{PEMBAHASAN}

Suku Bauzi tergolong semi
nomadis yang secara penuh memanfaatkan ekosistem yang ada di daerah teritorinya. Mereka hidup dalam kelompok-kelompok kecil, berasarkan marga dengan tempat tinggal yang sangat sederhana, yang mudah untuk dipasang dan dibongkar dengan cepat. Masing-masing marga menguasai suatu areal sagu di dekat sungai. Kehidupan suku Bauzi tergolong dalam perekonomian pemburu dan pengumpul makanan. Bellwood (2000:243) berpendapat perekonomian pemburu dan pengumpul makanan di Papua sejak masa Pleistosen akhir hingga saat ini bukanlah pertanian yang sistematis.
Suku Bauzi memanfaatkan areal-areal yang bisa diakses dengan perahu dan jalan-jalan setapak di hutan. Jarak perjalanan dengan menggunakan perahu ke bagian dalam hutan bergantung pada ketinggian air dan ukuran perahu. Aktivitas berburu, menangkap ikan dan meramu merupakan aktivitas yang dilakukan sepanjang tahun, akan tetapi banyak spesies yang hanya tersedia secara musiman. Hal ini tidak saja berlaku terutama untuk buah-buahan dan sayur-sayuran hutan hujan, tetapi juga untuk spesies ikan dan hewan buruan. Sebagai contoh, babi hutan diburu sepanjang tahun sementara untuk kura-kura dan sejumlah spesies burung hanya pada musim-musim tertentu. Selama periode mencari makanan dan berburu dalam hutan hujan di dataran rendah, ada kemungkinan mereka menanam pisang dan ubi kayu yang tidak banyak memerlukan perhatian. Tanaman ini dipanen dan digunakan untuk perburuan selanjutnya pada lokasi yang sama atau berdekatan.

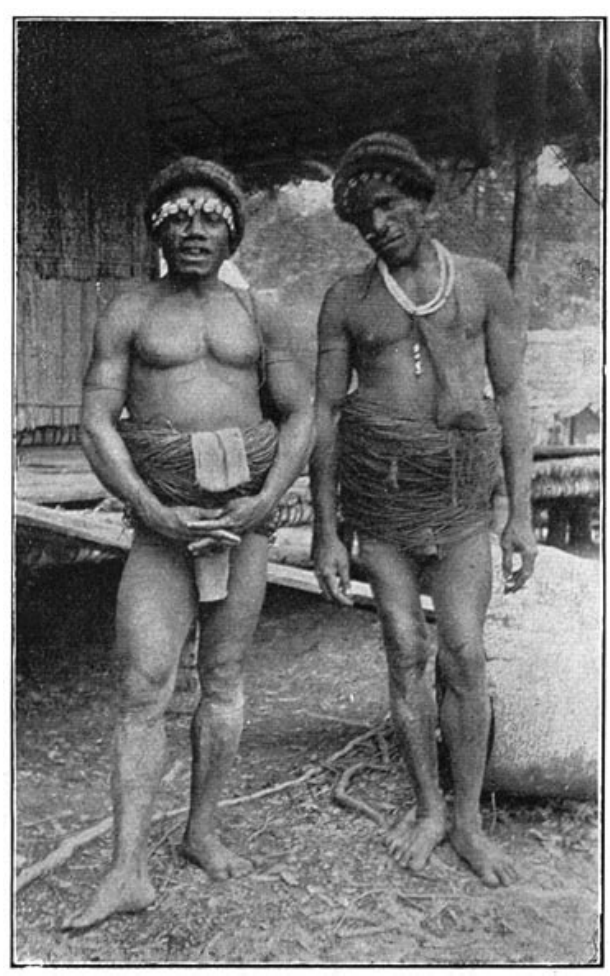

Gambar 1. Suku Bauzi (sumber: J. W. Langeler dan L. A. C. M. Doorman, 1918) 
Suku Bauzi suka memelihara anak babi hasil tangkapan, beternak babi bukanlah termasuk aktivitas utama mereka. Babi diburu dan dibunuh di tempat, bersama dengan beragam binatang-binatang berkantung seperti kanguru, bandikut, dan kuskus. Binatang buruan lain adalah kasuari dan jenis burung lainnya, kelelawar, biawak dan kura-kura.

Berburu dan meramu lebih tepat dapat dikatakan sebagai sebuah proses adaptasi terhadap lingkungan, sesuai dengan tingkat kemampuan teknologi yang dimiliki (Simanjuntak, 2006:2426). Berburu merupakan kegiatan bagi keakraban kaum pria sejak dulu, dan para pria senang menceritakan dan mengulangi cerita perburuan mereka saat pulang ke rumah. Berburu juga dianggap sebagai kegiatan untuk bertukar pengetahuan tentang alam, dan mempelajari kebiasaan binatang serta melatih fisik untuk bisa bergerak dengan cepat.

Pengintaian biasanya digabungkan dengan strategi lainnya, seperti penyerangan mendadak: bersembunyi dan menunggu di dekat pohon yang menghasilkan makanan yang disukai binatang, di tempat-tempat binatang intaian mencari minum, di pohon-pohon tempat burung jantan memancing perhatian si betina, dan di daerah yang lebih rendah dengan merobohkan dan membelah pohon-pohon sagu guna memancing babi-babi hutan mendekat dalam jarak sasaran panah. Untuk berburu babi hutan, tombak dibuat dari kayu besi. Tetapi, biasanya perburuan dilakukan oleh satu atau dua lakilaki. Senjata yang digunakan adalah busur dan panah serta tombak. Anjinganjing membantu menemukan dan memojokkan hewan-hewan berukuran besar, terutama kasuari dan babi-babi liar. Kedua binatang ini dapat dapat menjadi binatang berbahaya yang mematikan bagi para pemburu.

Kadangkala, perburuan melibat- kan sekelompok laki-laki yang menggiring hewan buruan kepada pemburu-pemburu yang sedang menunggu atau babi digiring oleh anjing-anjing ke suatu tempat di mana ada orang yang telah bersiap berjaga untuk menembaknya dengan panah. Sering kali satu regu pergi berburu babi pada malam hari. Seekor anjing pemburu yang baik, kerap kali diperkuat dengan kekuatan magis, adalah aset berharga bagi pemiliknya. Bila dipinjam dari pemiliknya, harus ada pembayaran yang harus dipenuhi. Anjing yang dibawa penutur Austronesia (Suroto, 2010:55) berjenis Canis familiaris hallstromi.

Pemasangan perangkap adalah metode yang lazim dilakukan, yaitu dengan membuat lubang tersembunyi atau lubang dengan umpan dan jaring yang siap dijatuhkan saat buruan masuk dan tali perangkap. Kebanyakan kegiatan berburu menggunakan jerat simpul, yaitu menggunakan simpul hidup yang terbuat dari tali, dengan umpan potongan sagu. Berbagai perangkap digunakan untuk menangkap buruan, yang umum digunakan adalah perangkap simpul tali.

Jerat dibuat dari sebatang pohon bambu atau kayu. Bambu atau kayu ini dipotong kira-kira panjangnya 5 meter dan dibersihkan dahannya. Kemudian bambu atau kayu ini dilengkapi atau diberi tali dari kulit pelepah sagu yang masih muda. Selain tali kulit pelepah sagu dapat juga dipergunakan tali pohon. Selesai dilengkapi dengan tali tersebut maka batang bambu atau kayu bagian yang besar ditanam ke dalam tanah lalu ujungnya dibengkokkan dan tali pada ujung bambu atau kayu tersebut dikaitkan pada sepotong kayu yang disiapkkan jika binatang menginjak kayu tersebut maka kakinya terikat dan terangkat ke atas.

Selain memasang umpan, para pemburu kerap menggunakan tipuan 
yang juga bisa berhasil. Misalnya getah pohon diulaskan pada cabang-cabang pohon untuk memperdaya burungburung, hal ini dilakukan terutama pada pohon-pohon buah atau rantingranting yang digunakan burung-burung jantan bertengger. Karena binatang kerap memiliki tempat tidur tetap, para pemburu umumnya mencoba menangkap sasaran mereka sebelum matahari terbit.

Proses pembuatan busur dan anak panah oleh Suku Bauzi. Busur berbahan dari kayu nibung, bambu dan kayu yang sudah tua. Kemudian nibung, bambu dan kayu ini dipotong dan dibelah-belah sesuai ukuran yang dikehendaki. Kayu palem hitam adalah pilihan terbaik untuk membuat busur. Pada ujung busur dibuat agak kecil dan meruncing jika dibandingkan dengan bagian tengahnya. Kedua ujungnya diberi simpul-simpul tali yang dibuat dari rotan. Untuk merentangkan busur disiapkan tali rotan yang telah dibelah dan dibersihkan. Selanjutnya belahan rotan tersebut dikaitkan pada kedua ujung busur. Proses pembentukan busur-busur ini adalah pekerjaan yang halus dan teliti, untuk menghasilkan lengkungan busur yang tipis dengan variasi lebar di sepanjang busur tersebut.

Anak panah terdiri dari tangkai dan mata. Untuk membuat tangkai anak panah diambil dari sejenis tebu hutan yang sudah tua. Tebu hutan ini dipotong lalu dipanaskan di atas api (diasapi) agar tahan lama dan mudah meluruskannya. Kemudian tangkai ini dipotong menurut ukuran yang dikehendaki. Mata panah dilem dengan getah pohon yang lengket dan diikat dengan rotan. Selain itu, mata panah diambil dari belahan nibung, tulang hewan atau belahan buluh bambu. Belahan nibung dan buluh bambu dipotong dan dibentuk meruncing bergerigi. Selanjutnya untuk menghubungkan mata panah dengan tangkainya terlebih dahulu diikat dengan tali rotan pada pangkal tangkai anak panah. Kemudian anak panah dimasukkan pada tangkainya. Pada sambungan mata anak panah dan tangkai diberi perekat dari getah sukun agar lilitan tali rotan pada pangkal tangkai menjadi lebih kuat.

Terdapat empat jenis anak panah: jenis anak panah besar, berujung tumpul, berkepala bulu untuk menjatuhkan burung, terutama burungburung dengan bulu berharga; anak panah berujung tulang atau kayu keras untuk berburu binatang berukuran sedang dan sebagian jenis burung; anak panah dengan ujung bercabang untuk berburu burung-burung kecil dan binatang menyusui; serta anak panah yang terbuat dari bambu untuk berburu babi.

Suku Bauzi juga mempergunakan tombak dalam berburu, alat ini dibuat dari kayu nibung atau sejenis kayu keras. Mata tombak dibuat runcing. Tangkainya bulat dan panjangnya 3-4 meter. Binatang utama yang diburu oleh suku Bauzi adalah babi (Sus Scrofa), tapi dalam perjalanan orang sering juga memanah beraneka jenis binatang yaitu walabi kecil (Darcopsulus sp. nou), tikus pohon kecil (Pogonomys sp. nou), rusa (cervus Timorensis), tikus tanah (bandicoot sp.), maleo (Mengapolius sp.), cenderawasih (Paradise sp.), kakatua (Cacatua sp.), ayam hutan (megapodius freycinet), kasuari (Casuarius casuarius), kanguru pohon (Dendrolagus Pulcherrimus), kuskus (Phalanger), paniki (Nyctimene), buaya muara (Crocodile porossus) dan buaya air tawar (Crocodile novaquinea). Buaya pada musim kering kebanyakan bersarang pada hamparan vegetasi terapung.

Buaya diburu untuk diambil kulit dan dagingnya, kulit buaya sangat mahal harganya. Kegiatan berburu buaya ini dilakukan pada malam hari. 
Teknik berburu buaya secara tradisional memiliki ciri khas, untuk menangkap buaya beberapa pria harus menyelam. Alat yang dipakai hanya tali rotan. Kadang pemburujugamempergunakan alat penikam. Bahan untuk membuat alat penikam yaitu kayu nibung. Proses pembuatannya, mula-mula diambil pohon nibung dan dibelah. Selanjutnya belahan nibung dipotong dan diberi gerigi serta diruncingkan sebagai mata penikam menurut ukuran yang dikehendaki. Mata penikam ini terdiri dari enam batang lalu diikat dengan tali melinjo dan diberi perekat dengan getah sukun. Kemudian mata penikam dimasukkan pada tangkai buluh yang panjangnya 3 - 4 meter yang telah disiapkan. Selanjutnya mata penikam itu diikat lagi pada pangkal buluh.

Alat penikam buayayang matanya dibuat dari besi pembuatannya hampir sama dengan cara pembuatan pada nibung. Perbedaannya terletak pada waktu meruncingkan mata penikam. Mata penikam dari besi harus ditempa dan diruncingkan, sedangkan dari nibung langsung diruncingkan dengan senjata tajam. Bagian bilahnya dibuat dari logam bekas yang ditempa secara lokal yang diikat dengan menggunakan rotan.

Buaya yang dibunuh, dipotong dan bagian kulit berbentuk empat persegi dari bagian dimana kepala beerhubungan dengan leher dipisahkan untuk si pemburu. Dia akan menempatkan kulit ini di rumahnya karena di situlah roh dari buaya tersebut akan tinggal, dengan harapan kemudian akan lebih mudah untuk mendapatkan atau membunuh yang lain, karena titik ini merupakan pusat roh buaya. Daging hasil perburuan itu disantap. Sedangkan kulitnya dijual dengan harga tinggi. Suku Bauzi juga memanfaatkan lemak buaya digunakan untuk memasak sagu, selain itu juga digunakan sebagai obat malaria.

Tulang binatang buruan juga dimanfaatkan sebagai bahan alat. Jenis binatang yang dimanfaatkan tulangnya untuk alat adalah kus-kus dan kasuari. Untuk memperoleh tulang kasuari, mula-mula burung kasuari dipotong lalu bulunya diambil sebagai perhiasan, kemudian dagingnya dimakan. Tulang kasuari yang akan dibuat menjadi bakal senjata, dibersihkan dari daging. Setelah bersih, kemudian bagian ujung tulang yang mengecil dipecah. Sedangkan bagian pangkal tidak dipecahkan sebab dijadikan sebagai tempat pegangan. Selesai dipecahkan lalu diperhalus dengan batu pengasah, belahan bambu dan kulit siput, sehingga membentuk bakal senjata yang dikehendaki. Pekerjaan mengasah ini dilaksanakan berulangulang sehingga tulang ini menjadi runcing. Menurut Soejono (1998:10) tradisi pembuatan alat tulang sudah ada di Papua sejak masa Pleistosen hingga kini.

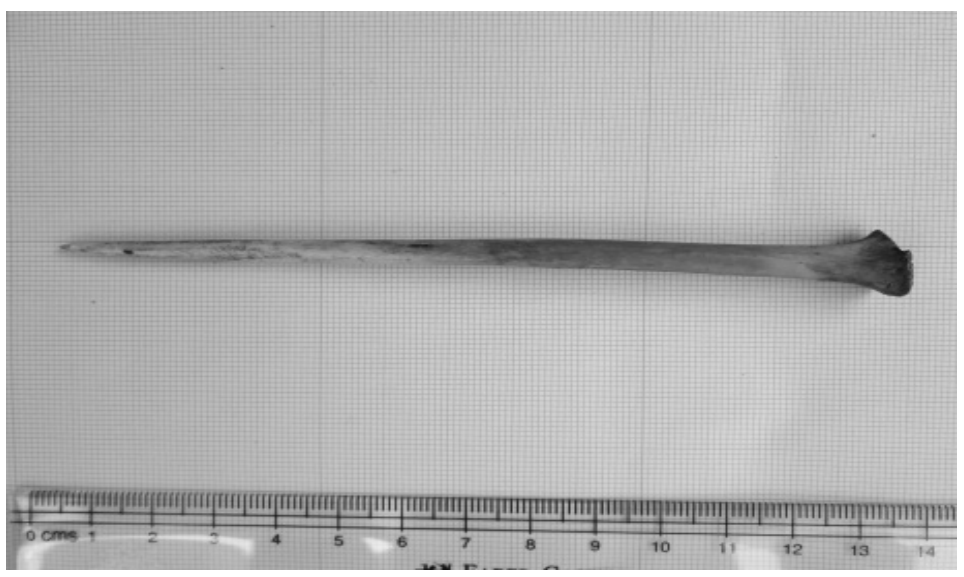

Gambar 2. Alat tusuk dari tulang kuskus (dokumentasi Balai Arkeologi Jayapura) 
Untuk memasak daging buruan, suku Bauzi mengenal batu api untuk membuat api. Batu api berjenis batu klastik, warna hitam dan tekstur keras. Batu ini banyak terdapat di tepi Sungai Mamberamo. Cara membuat api dengan batu ini yaitu memukul batu api dengan bambu dekat bulu kering dari pohon palem hitam, sehingga lentikan batu membakar bulu itu dan dengan beberapa tiupan saja api sudah dapat menyala. Batu api berwarna hitam, jenis batuan klastik.

\section{PENUTUP}

Kondisi lingkungan berpengaruh pada pola pemilihan tumbuh-tumbuhan dan hewan yang dikonsumsi suku Bauzi. Berburu binatang merupakan aktivitas suku Bauzi yang dilakukan sepanjang tahun. Binatang yang diburu adalah babi, rusa, binatang berkantung dan burung. Senjata yang digunakan adalah busur, panah, tombak, dan jerat simpul. Metode berburu yang digunakan yaitu berburu yang dilakukan individu, berburu kelompok, serta berburu kelompok menggunakan anjing. Strategi yang digunakan dalam berburu yaitu pemasangan perangkap, pengintaian serta penyerangan mendadak, menyelam dan menyerang buaya dalam air. Daging binatang hasil buruan dikonsumsi sedangkan tulangnya dimanfaatkan sebagai bahan alat. Alat tulang adalah perkakas yang dibuat dari bahan tulang yang dimanfaatkan dalam kehidupan seharihari suku Bauzi. 


\section{DAFTAR PUSTAKA}

Bellwood, Peter. 2000. Prasejarah Kepulauan Indo-Malaysia. Jakarta: Gramedia Pustaka Utama.

Deetz, James. 1967. Invitation to Archaeology. New York: The Natural History Press.

http://lightbeing.org diakses 31 Mei 2012 pukul 13.00 WIT.

http://www.mamberamorayakab.go.id diakses 31 Mei 2012 pukul 13.00 WIT.

Koentjaraningrat. 1963. "Orang Timorini" dalam Koentjaraningrat dan Harsja W. Bachtiar eds. Penduduk Irian Barat. Jakarta: PT Penerbitan Universitas. HIm. 216-231.

Muller, Kal. 2008. Mengenal Papua. Daisy World Books.

Lamera, J. dan L. Siregar. 1994. "Masyarakat Bauzi Danau Bira Mamberamo Tengah" dalam Koentjaraningrat (ed.). Irian Jaya Membangun Masyarakat Majemuk. Jakarta: Djambatan. HIm. 214-229.

Langeler, J. W. dan L. A. C. M. Doorman. 1918. Niew-Guinee en de Exploratie der “meervlakte' De Aarde en haar Volken. KITLV Leiden.

Reuter, Susanne. 2010. Ketika Injil Bersinar di Yalimo. Germany: Wahine.

Simanjuntak, Harry Truman. 2006. "Pluralisme dan Multikulturalisme dalam Prasejarah Indonesia. Penelusuran Terhadap Akar Kemajemukan Masa Kini”. Orasi Pengukuhan Profesor Riset Bidang Studi Prasejarah. Jakarta: Pusat Penelitian dan Pengembangan Arkeologi Nasional.

Soejono, R. P. 1998. "Indonesia dalam Lingkup Prasejarah Asia Tenggara dan Pasifik" dalam Dinamika Budaya Asia Tenggara-Pasifik dalam Perjalanan Sejarah. IAAI Komda Jawa Barat.

Suroto, Hari. 2010. Prasejarah Papua. Denpasar: Udayana University Press. 